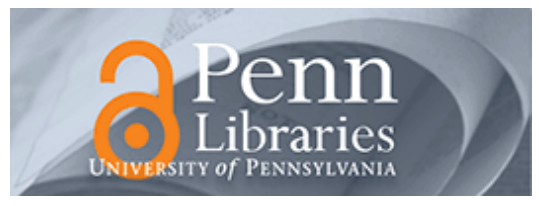

University of Pennsylvania ScholarlyCommons

Finance Papers

Wharton Faculty Research

$5-2016$

\title{
Borrowing Constraints and Homeownership
}

Arthur Acolin

University of Southern California

Jesse Bricker

The Board of Governors of the Federal Reserve System

Paul Calem

Federal Reserve Bank of Philadelphia

Susan Wachter

University of Pennsylvania

Follow this and additional works at: https://repository.upenn.edu/fnce_papers

Part of the Finance Commons, Finance and Financial Management Commons, and the Real Estate Commons

Recommended Citation

Acolin, A., Bricker, J., Calem, P., \& Wachter, S. (2016). Borrowing Constraints and Homeownership. American Economic Review, 106 (5), 625-629. http://dx.doi.org/10.1257/aer.p20161084

This paper is posted at ScholarlyCommons. https://repository.upenn.edu/fnce_papers/236

For more information, please contact repository@pobox.upenn.edu. 


\title{
Borrowing Constraints and Homeownership
}

\author{
Abstract \\ This paper identifies the impact of borrowing constraints on homeownership in the U.S. in the aftermath \\ of the 2008 financial crisis. While homeownership declines and tightened credit are evident, the role the \\ tightening of credit has had on the probability of individual households to become homeowners has not \\ been previously identified. The homeownership rate in 2010-2013 is estimated to be 2.3 percentage \\ points lower than if the constraints were set at the 2001 level. \\ Disciplines \\ Finance | Finance and Financial Management | Real Estate
}




\title{
Borrowing Constraints and Homeownership
}

\author{
By Arthur Acolin, Jesse Bricker, Paul Calem, and Susan Wachter*
}

Borrowing constraints enable lenders to manage risk using non-price terms in the presence of imperfect information but also impact the ability of households to become homeowners. Some individual households' welfare would improve if constraints were lifted. However, as the subprime crisis demonstrates, indiscriminately lifting borrowing constraints increases risk in the mortgage market unsustainably and can entail systemic risk.

The literature has identified three constraints that limit access to mortgages: wealth (through maximum loan to value ratio); income (through maximum debt to income ratio); and credit (through minimum credit score). Households with insufficient wealth or income (relative to their preferred housing consumption and local house prices) or an inadequate credit score are unable to become owners even if that would be the optimal tenure based on their preferences, expected duration of residence, and user cost of owning relative to renting.

Changes in the mortgage market can lead to relaxed borrowing constraints, expanded access to mortgages, and increased homeownership. Whether such credit expansions are sustained depends on the ability of financial markets and

\footnotetext{
*Acolin: University of Southern California, 650 Childs Way, Los Angeles, CA 90089 (e-mail: acocapid@usc.edu); Bricker: Board of Governors of the Federal Reserve System, 20th and C Street, NW, Washington, DC 20551 (e-mail: jesse.bricker@frb.org); Calem: Federal Reserve Bank of Philadelphia, 10 Independence Mall, Philadelphia, PA 19106 (e-mail: paul.calem@phil.frb.org); Wachter: University of Pennsylvania, 430 Vance Hall, 3733 Spruce St., Philadelphia, PA 19104 (e-mail: wachter@wharton.upenn.edu).The analysis and conclusions set forth are those of the authors and do not indicate concurrence by other members of the research staff or the Board of Governors or the Federal Reserve Bank of Philadelphia. We thank our discussant Shane Sherlund for valuable comments. Wachter gratefully acknowledges support from the Research Sponsors Program of the Zell/Lurie Real Estate Center at Wharton.

${ }^{\dagger}$ Go to http://dx.doi.org/10.1257/aer.p20161084 to visit the article page for additional materials and author disclosure statement $(\mathrm{s})$.
}

regulations to ensure proper risk management and assessment.

The first section reviews evidence of the existence of credit rationing in the US mortgage market. The second section discusses the impact of borrowing constraints on homeownership outcomes post World War II. The third section presents new estimates of the effect of borrowing constraints in the aftermath of the 2008 financial crisis.

\section{Credit Rationing and Homeownership}

Stiglitz and Weiss (1981) develop a model in which lenders ration access to credit using non-price terms. Lenders' ability to risk-base price is limited by the high transaction and information costs associated with estimating credit risk, the presence of unobservable characteristics that affect credit risk, and the effect of higher interest rates on adverse selection and moral hazard. The empirical literature provides evidence of credit rationing in the mortgage market (Duca and Rosenthal 1994). Lenders use non-rate terms to limit adverse selection associated with higher interest rates or moral hazard for borrowers with little collateral. In this context, borrowers who cannot meet a minimum down payment requirement, for example, will not be able to obtain a mortgage even if they are willing to pay a higher interest rate.

Due to the reliance on access to credit to purchase a home, the mortgage borrowing constraints that arise from credit rationing affect households' tenure (and the quantity of housing services they consume). Linneman and Wachter (1989) show that wealth and income constrained households have a lower propensity to be homeowners. ${ }^{1}$

\footnotetext{
${ }^{1}$ Duca and Rosenthal (1994) and Rosenthal (2002) find similar results, as does Haurin, Hendershott, and Wachter (1996) with wealth endogenized.
} 
The literature shows that young and minority households are particularly impacted by borrowing constraints. Haurin, Hendershott, and Wachter (1996) find that young households are more likely to be constrained and that being constrained has a large effect on the propensity of a young household to own. Barakova et al. (2003) look at recent movers under age 50 in 1989, 1995, and 1998 among households comprising the Federal Reserve Board's Survey of Consumer Finances and estimate that homeownership would double from about 30 percent to about 60 percent in that population if constraint removal were feasible. Examining differences across white and minority households, Gyourko, Linneman, and Wachter (1999) find that minority households are both more likely to be wealth constrained and less likely to be homeowners when constrained. Their results do not indicate significant differences across races in the homeownership rate of unconstrained households.

These studies were conducted in periods with moderate house price appreciation, which would tend to limit the binding impact of borrowing constraints. Rapidly rising house prices contribute to increasing the demand for homeownership due to backward looking higher expectations for price appreciation (Case and Shiller 1989). With rising house prices, constraints become more binding increasing pressure to relax them; and the level of constraints themselves may become endogenous and procyclical, contributing to financial instability.

\section{Borrowing Constraints and Homeownership Post-World War II}

In the post-World War II period we have seen three different mortgage lending regimes characterized by differing borrowing constraint conditions and homeownership outcomes. Borrowing constraints can change as the result of regulatory shifts or financial innovations or market pressures. The mechanism through which the loosening of constraints occurs has implications for the sustainability of the expansion of credit and homeownership access.

From 1940 to 1960 , the US homeownership rate increased by almost 20 percentage points, from 44 percent to 62 percent (US Census Bureau 2015). New government entities in the mortgage market, established in the aftermath of the Great Depression, specifically FHA and the secondary market institution Fannie Mae, along with the economic expansion that followed World War II, contributed to this rise. According to Fetter (2013), the self-amortizing long-term fixed rate mortgage with lower down payments, introduced by FHA, was a major factor in this rapid and large increase.

For the subsequent three decades of this postWorld War II regime, between the 1960s and the 1990s, homeownership remained stable. The conventional self-amortizing 30-year fixed rate "American" mortgage (Green and Wachter 2005) provided housing finance, funded by banks and S\&Ls, through deposits, until the 1980s. ${ }^{2}$ In the aftermath of the S\&L crisis, in the 1980 s and the 1990s, this instrument continued to prevail, funded by the secondary market. ${ }^{3}$ Despite substantial population growth and increasing inflation over this period, housing remained affordable due to this instrument, rising incomes, and an elastic housing supply.

Starting in the late 1990s, but accelerating during the years 2003 to 2007, a combination of regulatory shifts, changes to the structure of the mortgage market, and rising house prices, generated the second mortgage lending regime, which would prove to be turbulent (McCoy, Pavlov, and Wachter 2009). The expansion of credit in the latter part of this period was quite dramatic. ${ }^{4}$ The number of purchase mortgages originated increased from 4.3 in 2001 to 5.7 million in 2004 and remained above 5.5 million through 2006 (FFIEC 2015).

This increase in debt was not the result of changes in underlying debt repayment capacity of households (such as a positive shock to permanent income) but of changes in credit supply (Levitin and Wachter 2012). During the same

\footnotetext{
${ }^{2}$ In this period mortgages were effectively rationed. Competition for deposits was limited due to Regulation Q deposit rate ceilings. Similarly, deposit-taking institutions did not compete for mortgage borrowers on rate.

${ }^{3}$ Securitized mortgages through the GSEs funded the long-term fixed rate mortgage after rising inflation decapitalized the S\&Ls. The "housing finance revolution" ended deposit regulation and linked housing finance markets to credit markets (Green and Wachter 2005). The GSEs continued to impose credit constraints for "prime" mortgages that they guaranteed (Levitin and Wachter 2012).

${ }^{4}$ There is some evidence of the GSEs expanding credit (Frame et al. 2015), while borrowing constraints remained close to historical levels before the early 2000s (Rosenthal 2002).
} 
period, household debt increased faster than income (Mian and Sufi 2015), driven by the increasing volume and market share of nontraditional mortgages (NTM), subprime lending, and second liens.

Gabriel and Rosenthal (2015) show that age specific homeownership rates increased after 2000 beyond levels explainable by observables. Barakova, Calem, and Wachter (2014) show that, in the years 2003 to 2007, credit constraints eased considerably relative to historic norms. National homeownership rates peaked in 2004. Despite the easing of lending constraints, rising house prices increased the share of households affected by constraints (Barakova, Calem, and Wachter 2014).

Debates exist as to where credit was directed: to minority and low-income households (Mian and Sufi 2015); across the entire income spectrum (Adelino, Schoar, and Severino 2015; Acolin, An, Bostic, and Wachter 2015); or to investors (Haughwout et al. 2011).

As the credit expansion took place, the market share of subprime and NTM products increased, but neither the risk characteristics of the mortgages issued, nor how the risk was priced, was known (Levitin and Wachter 2012). In the aftermath, we now know that rising prices and price expectations were associated with increased NTM issuance (Brueckner, Calem, and Nakamura 2012; Pavlov and Wachter 2011)

As house prices peaked in January 2006 and then rapidly declined, with subprime and NTM issuance going near zero, over a third of US homes with mortgages fell "underwater." Plummeting collateral values and a weakening economy, combined with the risky characteristics of the loans originated during the boom period, drove foreclosure rates to their highest ever recorded levels. In response, a third regime shift took place.

\section{Borrowing Constraints and Homeownership After the Great Recession}

The homeownership rate declined from a high of 69 percent in 2004 to 63.7 percent in the third quarter of 2015 (US Census Bureau 2015).5 In response to high foreclosure rates

\footnotetext{
${ }^{5}$ The decline in homeownership was particularly pronounced among 30 to 39 -year-old household heads who
}

and "put-backs" to originators of defaulting mortgages, lenders and secondary market institutions tightened the "credit box." Evidence on credit availability, based on the characteristics of borrowers, indicate tightening of mortgage underwriting over the period 2008-2013 beyond historic norms (Goodman, Zhu, and George 2015). Nonetheless the impact of tightened credit on homeownership has not been estimated.

We estimate the impact of borrowing constraints on homeownership after the Great Recession using the Federal Reserve Survey of Consumer Finance (SCF) for 2010 and 2013 and compare these estimates to those obtained using previous (2001, 2004, and 2007) surveys (Acolin, Bricker, Calem, and Wachter 2015). The SCF has detailed information about household wealth and income and variables to impute a credit score based on the model developed in Barakova et al. (2003). In addition, with access to local information it is possible to estimate the (unconstrained) preferred house value for a household, given their place of residence, to identify constrained households.

We find that tightened borrowing constraints have a substantial negative impact on the probability of becoming a homeowner in the aftermath of the Great Recession. In the overall population, the estimated marginal decline in the likelihood of being an owner, associated with being subject to one or more of the three borrowing constraints (wealth, income, or credit), is 26 percent in 2001 and 23 percent in the period 2004-2007. Following the Great Recession (for the period 2010-2013), the marginal effect of being constrained is a 30 percent decrease in likelihood of owning - substantially larger than in 2001 and 2004-2007 (Table 1).

Table 2 presents predictions of the homeownership rate in the overall population in 2010-2013 compared to 2004-2007, the loosened credit regime, and compared to 2001, the historical credit regime. The homeownership rate in 2010-2013 is 5.2 percentage points lower

experienced a 10.4 percentage point decline between 2004 and 2014 (from 61.9 to 51.5 percent) compared to a 4.6 percentage point decline in the overall population. The current homeownership rate would be even lower without the aging of the population. At 2004 age structure, the homeownership in 2014 would be 62.8 percent instead of 64.5 percent (US Census Bureau 2015). 
Table 1-Borrowing Constraints Marginal Effects on Propensity to Own, Entire Population

\begin{tabular}{lccc}
\hline \hline & 2001 & $2004-2007$ & $2010-2013$ \\
\hline Borrowing constraint & $-0.26 * * *$ & $-0.23^{* * *}$ & $-0.30^{* * *}$ \\
& $(0.02)$ & $(0.01)$ & $(0.01)$ \\
Individual and local & $\mathrm{X}$ & $\mathrm{X}$ & $\mathrm{X}$ \\
controls & & & \\
\hline
\end{tabular}

Note: Robust standard errors in parentheses.

*** Significant at the 1 percent level.

** Significant at the 5 percent level.

* Significant at the 10 percent level.

Table 2-Predicted Homeownership Rate Based on Different Regime Constraints Coefficients

\begin{tabular}{lccc}
\hline \hline & 2001 & $2004-2007$ & $2010-2013$ \\
\hline $\begin{array}{l}\text { Predicted homeownership } \\
\text { rate }\end{array}$ & $67.3 \%$ & $68.9 \%$ & $66.2 \%$ \\
$\begin{array}{l}\text { Predicted homeownership } \\
\quad \text { rate: } 2001 \text { constraint }\end{array}$ & $65.2 \%$ & $68.5 \%$ \\
$\quad$ coefficient & & \\
$\begin{array}{l}\text { Predicted homeownership } \\
\text { rate: } 2004-2007\end{array}$ & & $71.4 \%$ \\
$\quad$ constraint coefficient & & & \\
\end{tabular}

than it would have been if the constraints were at the 2004-2007 level and 2.3 percentage points lower than if the constraints were set at the 2001 level.

\section{Conclusion}

The rationing of credit in the mortgage market due to imperfect information impacts households' propensity to own. In the post-World War II era, institutional shifts and mortgage product innovation increased access to mortgages and homeownership. In the decade 2000 to 2010 , changes in the mortgage market led to house price volatility, due to significant easing and then tightening of the credit box, to levels beyond historic norms and, ultimately to significant declines in homeownership rates.

\section{REFERENCES}

Acolin, Arthur, Xudong An, Raphael W. Bostic, and Susan M. Wachter. 2015. "Non-Traditional Mortgage Products and Homeownership." Unpublished.
Acolin, Arthur, Jesse Bricker, Paul Calem, and Susan Wachter. 2015. "Borrowing Constraints and Homeownership over the Recent Cycle." Unpublished.

Adelino, Manuel, Antoinette Schoar, and Felipe Severino. 2015. "Loan Originations and Defaults in the Mortgage Crisis: The Role of the Middle Class." National Bureau of Economic Research Working Paper 20848.

- Barakova, Irina, Raphael W. Bostic, Paul S. Calem, and Susan M. Wachter. 2003. "Does Credit Quality Matter for Homeownership?" Journal of Housing Economics 12 (4): 318-36.

-Barakova, Irina, Paul S. Calem, and Susan M. Wachter. 2014. "Borrowing Constraints during the Housing Bubble." Journal of Housing Economics 24: 4-20.

-Brueckner, Jan K., Paul S. Calem, and Leonard I. Nakamura. 2012. "Subprime Mortgages and the Housing Bubble." Journal of Urban Economics 71 (2): 230-43.

Case, Karl E., and Robert J. Shiller. 1989. “The Efficiency of the Market for Single-Family Homes." American Economic Review 79 (1): 125-37.

Duca, John V., and Stuart S. Rosenthal. 1994. "Borrowing Constraints and Access to Owner-Occupied Housing." Regional Science and Urban Economics 24 (3): 301-22.

Federal Financial Institutions Examination Council (FFIEC). 2015. Home Mortgage Disclosure Act Data. https://www.ffiec.gov/hmda/.

-Fetter, Daniel K. 2013. "How Do Mortgage Subsidies Affect Home Ownership? Evidence from the Mid-Century GI Bills." American Economic Journal: Economic Policy 5 (2): 111-47.

-Frame, W. Scott, Andreas Fuster, Joseph Tracy, and James Vickery. 2015. "The Rescue of Fannie Mae and Freddie Mac." Journal of Economic Perspectives 29 (2): 25-52.

- Gabriel, Stuart A., and Stuart S. Rosenthal. 2015. "The Boom, the Bust, and the Future of Homeownership." Real Estate Economics 43 (2): 334-74.

Goodman, Laurie, Jun Zhu, and Taz George. 2015. "The Impact of Tight Credit Standards on 2009-13 Lending." Washington, DC: Urban Institute.

-Green, Richard K., and Susan M. Wachter. 2005. "The American Mortgage in Historical and International Context." Journal of Economic Perspectives 19 (4): 93-114. 
Gyourko, Joseph, Peter Linneman, and Susan Wachter. 1999. "Analyzing the Relationships among Race, Wealth, and Home Ownership in America." Journal of Housing Economics 8 (2): 63-89.

Haughwout, Andrew, Donghoon Lee, Joseph Tracy, and Wilbert van der Klaauw. 2011. "Real Estate Investors, the Leverage Cycle, and the Housing Market Crisis." Federal Reserve Bank of New York Staff Report 514.

Haurin, Donald R., Patric H. Hendershott, and Susan M. Wachter. 1996. "Borrowing Constraints and the Tenure Choice of Young Households." National Bureau of Economic Research Working Paper 5630.

Levitin, Adam J., and Susan M. Wachter. 2012. "Explaining the Housing Bubble." Georgetown Law Journal 100 (4): 1177-1258.

-Linneman, Peter, and Susan Wachter. 1989. "The Impacts of Borrowing Constraints on Homeownership." Real Estate Economics 17 (4): 389-402.

McCoy, Patricia A., Andrey D. Pavlov, and Susan M. Wachter. 2009. "Systemic Risk through
Securitization: The Result of Deregulation and Regulatory Failure." Connecticut Law Review 41 (4): 1327-75.

Mian, Atif R., and Amir Sufi. 2015. "Fraudulent Income Overstatement on Mortgage Applications during the Credit Expansion of 2002 to 2005." National Bureau of Economic Research Working Paper 20947.

- Pavlov, Andrey, and Susan Wachter. 2011. "Subprime Lending and Real Estate Prices." Real Estate Economics 39 (1): 1-17.

Rosenthal, Stuart S. 2002. "Eliminating Credit Barriers: How Far Can We Go?" In LowIncome Homeownership, edited by Nicolas P. Retsinas and Eric S. Belsky, 111-45. Washington, DC: Brookings Institution.

Stiglitz, Joseph E., and Andrew Weiss. 1981. "Credit Rationing in Markets with Imperfect Information." American Economic Review 71 (3): 393-410.

United States Census Bureau. 2015. Housing Vacancies and Homeownership: CPS/HVS Historical Tables. Washington, DC: US Census Bureau. 


\section{This article has been cited by:}

1. Arthur Acolin, Xudong An, Raphael W. Bostic, Susan M. Wachter. 2017. Homeownership and Nontraditional and Subprime Mortgages. Housing Policy Debate 27:3, 393-418. [CrossRef]

2. William M. Rohe. 2017. Tackling the Housing Affordability Crisis. Housing Policy Debate 27:3, 490-494. [CrossRef]

3. John V. Duca. 2017. The Great Depression versus the Great Recession in the U.S.: How fiscal, monetary, and financial polices compare. Journal of Economic Dynamics and Control . [CrossRef] 